\title{
Pragmatisme Partai Nasional Demokrat dalam Sistem Pemilu Terbuka
}

\author{
Hilda Yunita Wono ${ }^{1}$, Masad Masrur², Felita Purnomo 3 , Silvia Arviana ${ }^{4}$ \\ 1,3,4 Universitas Ciputra Surabaya, CBD Boulevard Citraland Surabaya, Indonesia \\ ${ }^{2}$ Universitas Sahid Jakarta, Sahid Sudirman Residence Jakarta, Indonesia \\ Contact: hilda.yunita@ciputra.ac.id
}

\begin{abstract}
The National Democratic (Nasdem) Party's strategy in facing the 2019 Election with an open proportional representation system is to recruit celebrities as voters. Their placement as candidates for state administrators risked injuring the substance and objectives of democracy, because candidates for state administrators must have certain ideologies and competencies as well as the replacement of ideological cadres by celebrities. This qualitative research uses the literature study method for data collection. The purpose of this study is to find out the pragmatism of the national democratic party in an open proportional electoral system. From the results obtained, political parties tend to leave ideological cadres rather than representing members and the wider community. The Nasdem Party finally saw that celebrities are part of professional actors who have the ability as celebrity politicians although in practice they play more roles as celebrity endorsers. Placement of celebrities as candidates for state administrators is a necessity for sales-oriented parties. However, it is necessary to consider the risks to the aims and substance of democracy.
\end{abstract}

Keywords: Nasdem Party, pragmatism, celebrity, General Election system, democracy

\begin{abstract}
ABSTRAK
Strategi Partai Nasional Demokrat dalam menghadapi Pemilu 2019 dengan sistem perwakilan proporsional terbuka adalah dengan merekrut selebriti sebagai pemilih. Penempatan mereka sebagai calon penyelenggara negara berisiko mencederai substansi dan tujuan demokrasi, karena calon penyelenggara negara harus memiliki ideologi dan kompetensi tertentu serta penggantian kader ideologis oleh selebriti. Penelitian kualitatif ini menggunakan metode studi Pustaka untuk pengambilan datanya. Tujuan dari penelitian ini ingin mengetahui pragmatisme partai nasional demokrat dalam sistem pemilu proporsional terbuka. Dari hasil yang didapatkan, partai politik cenderung meninggalkan kader ideologis daripada mewakili anggota dan masyarakat luas. Partai Nasdem akhirnya melihat selebriti adalah bagian dari aktor profesional yang memiliki kemampuan sebagai politisi selebriti meskipun dalam praktiknya lebih banyak berperan sebagai celebrity endorser. Penempatan selebritas sebagai calon penyelenggara negara menjadi kebutuhan bagi partai yang berorientasi pada penjualan. Namun, perlu dipertimbangkan risiko terhadap tujuan dan substansi demokrasi.
\end{abstract}

Kata Kunci: Partai Nasdem, pragmatisme, selebritas, sistem Pemilu, demokrasi

\section{Pendahuluan}

Adanya Undang-Undang No. 2 Tahun 1999 Tentangi Partai Politik sebagai tanda kebebasan politik di era reformasi tahun 1998, membuka peluang untuk kelahiran partai politik baru maupun kehadiran kembali partai politik lama dengan kemasan baru. Terdapat 141 partai politik disahkan sebagai badan hukum dari 184 parpol yang didirikan pada awal reformasi. Kualifikasi untuk dapat mengikuti partai politik hanya diberikan kepada 48 parpol dari jumlah yang ada. Jumlah partai politik yang dibentuk pun semakin banyak dalam menghadapi Pemilu 2004. Telah berdiri sekitar lebih dari 200 partai politik sebelum pemilu 2004. Dari jumlah tersebut, pengesahan sebagai badan hukum hanya diberikan kepada 50 partai politik dan hanya 24 partai politik yang terlibat Pemilu tahun 2004. Telah didirikan sekitar 132 partai politik 
pada Pemilu 2009, dan selain 16 partai politik lokal, terdapat sekitar 22 partai politik bisa mengikuti Pemilu karena berhasil melalui (Romli, 2011).

Progres partai politik di era reformasi, khususnya dalam visi, misi, program dan manajemen, cenderung ke arah electoral-professional parties, dimana pengelolaan partai politik makin melibatkan kalangan profesional dengan orientasi pasar. Pelibatan kalangan profesional ini menjadi sebuah kepastian, agar organisasi partai bisa memenuhi ekspektasi publik sebagai organisasi berkompeten dan moderen yang memadai dan diyakini sebagai sumber "satusatunya" untuk pengisian jabatan publik yang akan berdampak besar bagi masa depan masyarakat. Pengenalan pasar disini merupakan suatu proses dan kegiatan yang berkaitan dengan penciptaan kader partai serta pemuasan pemilih dengan cara menilai kebutuhan dan keinginan masyarakat.

Pelibatan kalangan profesional dengan orientasi pasar ini, berkembang sesuai dengan prinsip "supply" dan "demand" yang terjadi di masyarakat. Bukan hanya kepada partai politik, sistem Pemilu pun didorong untuk lebih terbuka terhadap peran masyarakat sebagai pemilik hak dipilih maupun hak memilih sesuai dengan model demokrasi deliberatif. Sesuai dengan model demokrasi deliberatif. Dalam dinamika masyarakat sipil, legitimitasi hukum bisa didapatkan dari diskursus karena model ini memberikan ruang keikutsertaan masyarakat dalam membentuk aspirasi dapat dihargai secara setara. Model demokrasi deliberatif ini pula yang mendorong perubahan sistem Pemilu, agar lebih membuka peluang bagi tiap warganegara, tampil sebagai calon anggota legislatif.

Sejak tahun 2009, Mahkamah Konstitusi (MK) memutuskan sejak 2009 agar Pemilu digelar dengan sistem proporsional terbuka setelah pada beberapa Pemilu sebelumnya menggunakan sistem proporsional tertutup pada tahun 2008 melalui Putusan Nomor 22 dan 24/PUU$\mathrm{VI} / 2008$. Meskipun sistem proporsional terbuka dianggap mampu menghindari suara pemilih terbuang dan memfasilitasi keragaman kelompok sosial dalam menempatkan wakilnya, namun sistem ini juga dianggap berpotensi mengurangi peran partai politik, menciptakan pertarungan antarkandidat di internal partai, dan menciptakan ruang politik uang (Ramdani \& Arisandi, 2014).

Oleh partai Politik, sistem proporsional terbuka disikapi dengan berbagai strategi. Di satu sisi, partai-partai politik mengarah pada electoral-professional, namun dalam praktiknya, juga melakukan beberapa upaya yang dianggap pragmatis dan mereduksi perannya. Partai-partai politik menampilkan figur yang unggul popularitas, terutama dari kalangan artis dan selebritas. Figur populer dianggap sebagai bagian dari profesionalitas dalam komunikasi karena mereka relatif dikenal publik. Hasil Pemilu menunjukkan, pada Pemilu 2009 terdapat 18 selebritas terpilih. Sedangkan pada Pemilu 2014, terpilih 15 selebritas, dan pada tahun 2019 terpilih 14 selebritas (Wicaksono \& Aziz, 2020).

Selebriti diartikan sebagai penarik suara (vote-getter) untuk partai politik dengan sarana popularitasnya (Jati, 2014). Namun, kelindan antara selebritas dan partai politik yang bermuara pada kemenangan Pemilu semata-mata, beresiko mencederai demokrasi yang bertujuan memperoleh kader-kader terbaik partai dalam memperjuangkan ideologi, platform, dan visi partai (Dugaswara, 2019). Demokrasi akan tercederai jika sebagai calon penyelenggara negara, 
akan terbawa watak selebritas atau pengusaha, dan bukan berjiwa melayani dan mementingkan masyarakat. Kurang melembaganya proses rekrutmen anggota menjadi persoalan ini pula yang menghinggap pada partai politik. Beberapa kegiatan juga dilakukan kurang memadai, seperti rangkaian seleksi, pendidikan bagi para anggota, dan penjenjangan. Belum dilakukan secara melembaga oleh sebagian partai politik meskipun tidak semua partai politik melakukan hal seperti itu. Sebagian partai politik belum melakukan pola rekrutmen secara sistematik dan ajeg, terbukti dengan peristiwa terbentuknya "kader instan", kurang siapnya partai politik menunjuk perwakilan anggota sebagai legislatif atau eksekutif,(Romli, 2011).

Partai Nasional Demokrat (Nasdem) yang lahir jauh sesudah reformasi 1998, yaitu 16 Juli 2011, merupakan partai politik yang mengarah pada motivasi electoral yang pada awalnya berorientasi penjualan (sales-oriented partiy/SOP). Hal ini ditunjukkan melalui kebijakan dan strategi pemenangan di dua Pemilu yang diikutinya, yaitu tahun 2014 dan 2019. Mengikuti anggota Dewan Pakar Teuku Taufiqulhadi, sesuai yang dikabarkan Garnesia (2019), pada Pemilu 2019, Partai Nasdem memang memberi ruang terbuka untuk menjadi calon legislatif bagi selebritas. Karena diharapkan bisa menjadi basis dukungan dari basis penggemar. Bagi Partai Nasdem, "yang sering tampil maka dia yang dipilih" adalah rumus menang Pemilu yang cukup sederhana (Wicaksono \& Aziz, 2020).

Hasilnya, Partai Nasdem yang pada Pemilu 2014, memperoleh 6,72\% suara nasional melonjak menjadi 9,05\% suara nasional pada Pemilu berikutnya yakni tahun 2019. Keberhasilan menaikkan prosentase pemilih dinilai oleh berbagai pihak karena strategi penempatan calon legislatif yang unggul dari segi popularitas. Partai Nasdem pada keikutsertaan dalam Pemilu 2019, menempatkan 38 selebritas sebagai calon legislatif. Dibandingkan partai-partai lainnya, jumlah tersebut jauh lebih besar untuk selebritas yang dicalonkan, seperti Partai Demokrasi Indonesia Perjuangan (PDIP) yang menempatkan 12 selebritas atau Partai Amanat Nasional (PAN) yang melibatkan 9 selebritas (Fadhli, 2016; Wicaksono \& Aziz, 2020).

Aeron Davis (2019:56-61) menyampaikan bahwa, electoral-professional party yang berorientasi kepada pasar, menghasilkan konsekuensi lebih negatif daripada positif. Konsekuensi negatif ini diindikasikan dari besarnya pengaruh "promosi komersial" yang dilakukan partai politik sehingga menurunkan peringkat kebijakan. Partai-partai politik juga makin menjauh dari anggota dan makin mendekat kepada pendonor dan minat khusus (specials interest) (Crouch, 2004; Hay, 2007; Magleby, 2011; Hershey, 2017). Selain itu, partaipartai politik juga berorientasi pragmatis dalam menyikapi Pemilu. Pragmatisme partai politik ini merupakan imbas dari jumlah peserta Pemilu yang makin banyak (Pemilu multipartai), yang memunculkan persaingan sempurna (perfect competition) antarpartai. Terkait sikap pragmatis, pendapat Veblen (1914) mengatakan bahwa terdapat semacam logika untung-rugi, benefitdefisit, serta logika-logika matematis-ekonomis lain dalam diri manusia. Untuk mengetahui alasan pragmatisme partai, juga perlu diketahui motivasi partai politik dalam menghadapi Pemilu. Mengetahui latar belakang motivasi ini diperlukan, mengingat motivasi merupakan indikator penting untuk mengetahui alasan atas sikap yang dikedepankan oleh partai politik. 
Terkait motivasi, kebutuhan akan kekuasaan (need for power) adalah salah satu indikator dari motivasi tersebut. Selain itu, sorongan faktor luar, seperti sistem Pemilu, juga menjadi penting untuk diketahui pengaruhnya terhadap partai politik dalam memenangkan Pemilu, misalnya system Pemilu yang makin membuka keterlibatan publik.

Mengapa Partai Nasdem bersikap pragmatis dengan merekrut selebritas sebagai penjaring suara pada Pemilu 2019? Apa motivasi Partai Nasdem terkait hal ini? Sejauh mana penempatan selebritas sebagai Calon Legislatif merupakan bagian dari strategi untuk memenangkan Pemilu? Apakah penempatan selebritas sebagai penjaring suara akibat dari penerapan sistem proporsional terbuka?

\section{Metode}

Metode yang diusung adalah metode kualitatif yang dipakai menggunakan data pendekatan yang berlatar belakang anggapan filosofis dan penjelasan yang berasal dari berbagai sumber. Pengolahan data juga dikerjakan dengan memperhatikan keterkaitan data yang berdekatan dengan hasil yang diperoleh (Emzir, 2010). Menurut Nazir (2013), memaparkan penjelasan yang sesuai dengan kondisi realita merupakan tujuan dari metode penelitian deskriptif. Untuk memperoleh penjelasan tentang alasan Partai Nasdem bersikap pragmatis dalam pemelitian dengan merekrut selebritas sebagai penjaring suara pada Pemilu 2019 dikumpulkan berbagai bahan dari berbagai literatur. Selanjutnya juga dapat dilihat motivasi serta sejauh mana Partai Nasdem menempatkan selebritas sebagai Calon Legislatif yang merupakan bagian dari strategi untuk memenangkan Pemilu.

\section{Hasil dan Pembahasan}

Partai Nasdem adalah partai yang lahir dari rahim reformasi. Ketua umum Partai Nasdem kini dijabat oleh salah seorang yang sebelumnya merupakan petinggi Partai Golongan Karya (Golkar) yang tercatat pernah menjadi kandidat yang memerebutkan jabatan ketua umum partai periode 2009 yaitu Surya Paloh. Kekalahan Surya Paloh atas Abu Rizal Bakrie pada pemilihan ketua umum tersebut dinilai sebagai faktor yang menjadi alasan langkahnya untuk membuat Organisasi Massa Nasional Demokrat (Ormas Nasdem) pada 1 Februari 2010 oleh banyak kalangan. Surya Paloh merestui pembentukan Partai Nasdem yang didirikan oleh para pengurus Ormas Nasdem, yaitu Patrice Rio Capella, Sugeng Suparwoto, Ahmad Rofiq (Perdana, 2012).

Menurut pendiri Partai Nasdem, Sugeng Suparwoto, sebagaimana Perdana (2012), partai baru perlu lahir untuk menghilangkan peran partai karena partai yang eksis tidak lebih dari kartel yang memahami penelitian ekonimi politik secara bersamaan. Namun dalam prakteknya saling berkaitan anatra sembilan partai politik yang ada di DPR tidak lebih dari kepentingan pemahaman penelitian politik. Melalui pemanfaatan kepemilikan media, baik cetak maupun elektronik, Partai Nasdem memerkenalkan/menyosialisasikan diri kepada masyarakat dengan intensitas yang cukup tinggi. Karena tidak sedikit masyarakat yang menggabungkan diri dalam keanggotaan Partai Nasdem, maka hal itu yang membuat masarakat tertarik akan dinamika di dalamnya. 
Untuk mengakhiri "lingkaran setan" dan kebiasaan buruk dalam lingkup demokrasi dalam krisis kepercayaan rakyat kepada parpol, Partai Nasdem dibuat. Partai meminta kesadaran dan kekuatan dari masyarakat sebagai Gerakan Perubahan sebagai pemulihan Indonesia merupakan tujuan dari Partai Nasdem (Yudistira, 2015).

Sebagai partai baru, Nasdem lahir sebagai partai yang berorientasi penjualan. Perdana (2012) dalam tesisnya mengungkapkan bahwa riset pasar merupakan pembeda dari Sales Oriented Party (SOP) dan Market Oriented Party (MOP). pada SOP, penelitian pasar dilaksanakan setelah tahapan desain produk sedangkan MOP, riset pasar dilakukan di awal. Karena keluar Undang-Undang Nomor 2 Tahun 2011 yang menjelaskan perubahan UU Nomor 2 Tahun 2008 tentang Partai Politik, rencana Sugeng Suparwoto terkait Partai Nasdem yang akan melakukan pemeriksaan khusus kepada anggota Ormas Nasdem dengan anggota sebanyak 10 juta tidak jadi diselenggarakan akibat waktu yang terbatas.

Dominansi peran Surya Paloh dalam menjalankan komunikasi politiknya juga berkaitan dengan kelahiran Partai Nasdem. Partai ini lahir dari rancangan produk atas dasar keyakinan orang orang yang terlibat dan tidak didahului oleh riset pasar. Pesanketua umum Nasdem beserta tokoh lain di dalamnya jelas menggambarkan keyakinan akan produk politik Restorasi Indonesia.

Dalam persaingan politik diperlukan cara khusus untuk menarik minat dari para pemilik suara, terlebih di era multipartai, seperti juga pemasaran komersil. Ketika metode marketing politic menjadi proses penting di dalam komunikasi sebuah partai, peninjauan pasar menjadi tahapan pertama yang digunkan untuk mengetahui market sebuah partai yang sesungguhnya dan persaingan yang terjadi. Tiga hal untuk dapat memberikan pemahaman pesan komunikasi kepada masyarakat dalam political marketing, yaitu push, pull serta pass political marketing (Firmanzah, 2017). Hal ini pulalah yang dilakukan Partai Nasdem dalam menghadapi Pemilu.

Pendistribusian produk politik ke pemilik suara secara langsung disebut sebagai push political marketing. Pembangunan infrastruktur partai dari pusat hingga ke desa-desa dengan memilih calon yang berkompeten merupakan hal penting dalam strategi ini meski menguras tenaga, menyita waktu dan memakan biaya yang tidak sedikit. Kekuatan koneksi prasarana politik yang berasal dari "warisan Partai Golkar" masih dimiliki Partai Nasdem, mengingat Surya Paloh masih petinggi Partai tersebut pada saat Partai Nasdem mulai membentuk infrastruktur di daerah. Sementara sumber pendanaan partai, diperoleh dari Surya Paloh. Sedangkan cara efektif dalam memberikan pesan melalui seluruh media massa disebut pull political marketing. Cara khusus "serangan udara" dilakukan oleh Partai Nasdem melalui Media Grup milik Surya Paloh, jelas mampu membombardir pesan secara luas kepada khalayak.

Sedangkan cara efektif dalam memberikan pesan melalui seluruh media massa disebut pull political marketing. Inilah cara sebuah partai untuk memperkenalkan pesan-pesan politiknya menggunakan endorser. Jika tidak ada kemampuan partai untuk memilih endorser yang tepat, maka pesan akan diabaikan, dan bahkan akan ditolak. Pada posisi ini, Rio Capella tidak menyebutkan secara langsung strateginya yang mungkin dikarenakan strategi cukup baru dan perlu di olah ulang karena Partai Nasdem akan melibatkan 300 tokoh untuk di tinjau. 
Tabel 1. Gambaran kondisi Partai Nasdem dari sisi strategi politic marketing pada Pemilu 2014 dan Pemilu 2019

\begin{tabular}{|c|c|}
\hline \multicolumn{2}{|c|}{ Kondisi Partai Nasional Demokrat } \\
\hline Pemilu 2014 & Pemilu 2019 \\
\hline \multicolumn{2}{|r|}{ Push Political Marketing } \\
\hline $\begin{array}{l}\text { - Pembentukan infrastruktur, } \\
\text { "terdukung" oleh kekuatan } \\
\text { politik “warisan Partai } \\
\text { Golkar", mengingat Surya } \\
\text { Paloh masih petinggi Partai } \\
\text { tersebut pada saat Nasdem } \\
\text { mulai membentuk } \\
\text { infrastruktur ke daerah. }\end{array}$ & $\begin{array}{l}\text { - Infrastruktur telah lebih kuat dibanding saat masih } \\
\text { sebagai partai baru. Juga diperkuat dengan } \\
\text { pembentukan organisasi sayap partai. }\end{array}$ \\
\hline \multicolumn{2}{|r|}{ Pull Political Marketing } \\
\hline $\begin{array}{l}\text { - Media Grup milik Surya Paloh } \\
\text { mendominasi pesan kepada } \\
\text { khalayak. }\end{array}$ & $\begin{array}{l}\text { - Masih mengandalkan Media Grup milik Surya Paloh } \\
\text { mendominasi pesan kepada khalayak. }\end{array}$ \\
\hline \multicolumn{2}{|c|}{ Pass Political Marketing } \\
\hline $\begin{array}{l}\text { - Sebagai partai baru, Nasdem } \\
\text { belum memiliki banyak tokoh } \\
\text { sebagai endorser guna } \\
\text { memperkenalkan pesan- } \\
\text { pesan politiknya. }\end{array}$ & $\begin{array}{l}\text { - Mengambil langkah pragmatis dengan merekrut } \\
\text { puluhan selebritas populer sebagai endorser sekaligus } \\
\text { vote-getter dan calon legislatif. }\end{array}$ \\
\hline
\end{tabular}

Diolah dari berbagai sumber oleh penulis.

Sebagai partai baru, perolehan suara sebesar 6,72\% suara nasional pada keikutsertaan pertama pada Pemilu 2014, Nasdem dapat dikatakan sebagai partai yang cukup sukses. Kesuksesan ini melonjak menjadi 9,05\% pada Pemilu kedua pada Pemilu 2019, sehingga memunculkan penilaian bahwa sebagai pertai yang berorientasi penjualan (SOP), Nasdem cukup berhasil dalam menghadapi Pemilu. Salah satu strategi Partai Nasdem dalam memenangkan Pemilu 2019, adalah penempatan calon legislatif dari kalangan selebritas, menggeser kader-kader ideologis yang dimilikinya. Padahal, dalam penilaian sistem demokrasi, partai politik seharusnya lebih menempatkan kader ideologis yang memperjuangkan platform, dan visi partai. Orang-orang di dalam partai politik itu merupakan hal yang tidak boleh dilupakan. Dengan harapan akan lahir keputusan dan kebijakan yang berkualitas, dari tahap kualifikasi yang ketat untuk menentukan kualitas seseorang.

Sebagai partai baru, strategi pass political marketing menggunakan endorser yang memperkenalkan pesan-pesan politik, masih menjadi kelemahan bagi Partai Nasdem, karena belum ada tokoh yang bisa menjadi magnet electoral. Namun perolehan suara Partai Nasdem sebesar 6,72\% suara nasional pada keikutsertaan pertama di Pemilu 2014, diperoleh dari dua strategi lainnya yang lebih unggul, yaitu di push political marketing dan pull political marketing. Oleh karena itu, pada Pemilu kedua di tahun 2019, dengan mempertahankan strategi yang sama pada push dan pull political marketing, maka Partai Nasdem harus memperkuat pada strategi pass political marketing. 
Pada tahun 2014, terdapat sebanyak 79 orang selebritas yang mengikuti Pemilu. Sedangkan pada tahun 2019, sebanyak 59 orang selebritas yang mengikuti Pemilu. Dari 59 selebritas tersebut, 38 diantaranya dicalonkan oleh Partai Nasdem. Sekjen Partai Nasdem Johnny G. Plate, mengatakan bahwa di tingkat nasional terdapat potensi besar pada calon legislatif dari tokoh-tokoh terkenal. Selain terkenal, di daerah pemilihan mereka juga harus bisa menjadi basis elektoral. Karena seseorang belum tentu mempunyai elektabilitas di Daerah Pemilihan meskipun dikenal secara nasional (Rahayu, 2019).

Penempatan calon legislatif dari kalangan selebritas merupakan pilihan Partai Nasdem dalam memperkuat strategi pass political marketing. Strategi ini memang memerlukan endorser guna memperkenalkan pesan-pesan politik partai. Selebritas menjadi pilihan Partai Nasdem untuk menjadi endorser karena mereka memiliki popularitas sebagai modal awal dan langkah cepat sebagai vote-getter pada Pemilu yang akan segera dihadapi. Perekrutan selebritas, akhirnya menjadi pilihan pragmatis, mengingat strategi pass political marketing inilah yang menjadi titik lemah Partai Nasdem pada Pemilu 2014. Penguatan pass political marketing ini juga sangat diperlukan, mengingat strategi push dan pull political marketing masih sangat mengandalkan Surya Paloh sebagai pengusaha media.

Namun, tingkat keterpilihan selebritas Partai Nasdem pada Pemilu 2019 yang amat kecil, hanya 1 selebritas terpilih dibanding 38 calon yang dicalonkan, menunjukkan bahwa strategi partai dalam memenangkan Pemilu tidak cermat. Strategi, yang pada satu sisi menggeser peran kader ideologis demi menempatkan figur populis di sisi lain, menunjukkan bahwa tahapan kaderisasi Partai Nasdem tidak konstruktif. Penempatan figur-figur populer tersebut, dapat disebut sebagai bentuk pragmatisme politik dan hanya sebagai jalan pintas untuk memenangkan Pemilu. Rumus menang Pemilu "yang sering tampil maka dia yang dipilih", bukanlah rumus yang tepat dan tidak layak dikedepankan.

Celebrity politician dan celebrity endorser menjadi pembeda keterlibatan selebriti sebagai pendukung politik. Orang yang berasal dari kalangan yang memiliki citra adalah celebrity politician. Sedangkan celebrity endorser adalah seseorang yang pengakuannya sebagai cara untuk menarik perhatian sebagai iklan menurut. Mereka menambat empati untuk ikut memilih kandidat dengan cara menghibur dan menampilkan kreativitas di atas panggung.

Jika dirunut dari selebriti yang dipasang oleh Partai Nasdem, hampir tidak ada selebriti yang berposisi sebagai celebrity politician. Tercatat, beberapa selebriti seperti Okky Asokawati, Lucky Hakim, dan Krisna Mukti gagal terpilih kembali sebagai anggota legislatif ketika mencalonkan ulang menggandeng Partai Nasdem. Ketiga artis ini, karena pernah tercatat terpilih sebagai anggota legislatif, dapat disebut celebrity politician, yang posisinya berada di antara selebritas lain yang merupakan celebrity endorser (Garnesia, 2019). Di T provinsi yakni Jawa Barat, Jawa Tengah, Jawa Timur, serta DKI Jakarta terdapat pola pencalonan selebritas di kebanyakan partai politik, sehingga persaingan antarselebritas antarpartai terjadi di wilayahwilayah tersebut. Akhirnya, kualitas selebritaslah yang menentukan calon terpilih.

Kecilnya keterpilihan selebritas Partai Nasdem dalam menghadapi Pemilu 2019, sedikitbanyak, menunjukkan kualitas selebritas yang diusung oleh Partai Nasdem. Dengan hasil ini, makin jelas bahwa selebritas dalam pass political marketing Partai Nasdem dalam Pemilu 2019 
bukan menjadi faktor pendorong dalam menaikkan elektabilitas partai. Sejalan dengan hasil ini, Wicaksono dan Aziz (2020) mengatakan bahwa popularitas pada artis tidak sepadan dengan kadar elektabilitas sehingga calon dari kalangan artis tidak lagi di jadikan pilihan utama pemilik suara pada Pemilu. Selebritas tidak begitu dipilih oleh masyarakat dengan berbagai faktor. Pertama, partai hanya dianggap memilih selebritas sebagai pendompleng. Kebanyakan selebritas tinggal di ibu kota sehingga belum tentu paham karakteristik di daerah pemilihan. Faktor popularitas merupakan salah satu modal bagi selebritas, namun engagement antara selebritas dengan masyarakat, tidak diperhatikan. Masyarakat mengetahui bahwa rata-rata selebritas belum memahami apa yang harus dilakukan saat berhadapan dengan masyarakat meski ditunjuk oleh partai untuk turun ke daerah pemilihan yang ditentukan. Calon legislatif selebritas dalam berkampanye, harus didampingi tokoh masyarakat setempat dan hanya untuk diketahui bahwa selebritas tersebut menjadi wakil dari daerah pemilihan tersebut.

Kedua, masyarakat lebih melek dalam dunia politik dan banyak memperoleh informasi dari media sosial. Pada Pemilu 2019, 40\% dari total pemilih berasal dari generasi milenial (usia 1735 tahun) merupakan digital native. Perilaku keseharian selebritas yang hendak dipilih, tereferensi dengan lengkap di media digital yang ada dihadapan para pemilih tersebut. Masyarakat mengamati kesesuaian perlaku keseharian selebritas yang akan dipilihnya dengan kepentingan politik mereka.

Ketiga, partai politik dianggap gagal dalam mengimplementasikan fungsi rekrutmen politik. Secara konsep, sewajarnya partai politik berfokus melakukan kaderisasi berkualitas dalam mengisi pos-pos strategis jika sudah menjalankan fungsi rekrutmennya dengan baik. Namun pada Pemilu tahun 2019 dibuktikan bahwa yang menjadi focus pemilihan calon seperti "banjir selebritas", utamanya oleh Partai Nasdem, bukan terletak pada kualitas calon yang diusung.

Kecenderungan Partai Nasdem dalam menempatkan selebritas sebagai salah satu strategi pass political marketing, merupakan bentuk pragmatisme politik. Pragmatisme partai adalah akibat adanya keterlibatan logika untung-rugi, benefit-defisit, serta logika-logika matematisekonomis lainnya dalam memutuskan strategi partai. Sikap lebih berpihak pada pilihan yang tidak dilandaskan pada pemikiran yang matang dan penting melainkan dengan pemikiran yang singkat disebut sebagai pragmatisme. Riswandha (2004) mengatakan bahwa partai politik yang mengedepankan suatu hal penting dengan durasi singkat dengan menggeser nilai partai yang normatif disebut pragmatis. Dalam setiap aksinya, partai politik pragmatis akan mengesampingkan fungsi ideologi suatu partai. Selain mempertimbangkan pola berpikir untung rugi, ketetapan partai tidak lagi berdasarkan standing point ideologi.

Sikap pragmatis tersebut dapat dipengaruhi oleh beberapa sebab. Sebagaimana Darmawan (2015), penyebab pertama adalah, terjadi perubahan dari proporsional daftar tertutup ke proporsional daftar terbuka pada tata cara Pemilu. Pengaruh system ini berdampak pada dorongan untuk memilih tokoh yang memiliki modal kuat, seperti popularitas layaknya seorang artis. Terbukti pada Pemilu 2009 bahwa 60\% pemilik suara memilih tokoh calon legislative dibandingkan partai politik. Dalam upaya pemenangan Pemilu, partai politik lebih tertarik untuk menggandeng selebritas karena sudah memiliki modal popularitas yang cukup untuk dapat emmenangkan Pemilu (Belt, 2011). Strategi pemanfaatan selebritas sebagai kandidat 
merupakan pilihan rasional bagi parpol daripada membiyayai kader yang nantinya belum tentu bisa memenangkan Pemilu.

Berkaitan dengan perubahan sistem Pemilu menyebabkan parpol memutar otak untuk mendapat nominasi dengan menggandeng selebriti untuk ingin meraih dukungan pemegang suara. Dalam system porporsional terbuka, calon legislative mau tidak mau harus lebih melibatkan personal mereka untuk dapat dipilih oleh masyarakat. Kalangan artis menjadi kategori yang menuai banyak respon positif oleh para pemegang suara di bandingkan dengan kalangan non-artis. Oleh karena itu sistem ini memberikan atensi yang tinggi seiring dengan pendapat Menocal, n.d. (2011)

Kedua, pada awalnya berlandaskan aliran (ideologi partai politik) yang kemudian berubah ke arah byang berlandaskan pada perorangan dalam perilaku memilih pemilih Indonesia. Sindrom "idol" merupakan sebutan dari kecenderungan yang disebut oleh Kenawas dan Fitriani (2013) memiliki modal popularitas calon legislatif dari kalangan selebriti, dianggap memiliki peluang besar untuk dipilih. Ketiga, tata cara penerimaan dan seleksi calon tidak lagi menjadi fokus utama, melainkan pragmatisme parpol menjadi semakin

Makin mengarahnya partai politik kepada catch-all party memperlihatkan kecenderungan pragmatisme di tubuh partai politik, yaitu partai politik yang berusaha menarik diri dari pemegang suara dengan jumlah yang sedikit dan meraup semua segmen pemilih (Muhtadi, 2013). Catch all party di era multipartai terbentuk karena merupakan kelanjutan politik era Orde Baru sebagai penolakan ideologi kiri-kanan unruk dihilangkan. Pondasi pasar ekonomi yang mendasari kebijakan partai adalah logika produsen-konsumen, yang mengandaikan bahwa kreatifitas sebagai pengiring upaya politik dengan memberikan penawaran produk politik dlam persaingan. Kemudian, catch-all party memiliki potensi membentuk brntuk pemerintahan oligarki dalam sebuah partai karena personifikasi lembaga terus berjalan. Hal ini juga bertolak belakang dengan ciri khas parpol sebagai tonggak demokrasi.

Sikap pragmatis partai politik, juga dapat ditelusuri dari motivasi partai politik sebagai pelakunya. Motivasi akan pemenuhan kebutuhan kekuasaan (need for power), dapat dikatakan sangat mempengaruhi sikap partai politik. kemauan untuk mampu memiliki dampak, menjadi yang berdampak, dan mengambil alih yang lainnya disebut Kebutuhan kekuasaan. Sederhananya adalah kepentingan atas kekuasaan dan otonomi. Berbagai kaidah konstitusional, dilakuakan untuk menjalankan kebijakan-kebijakan Partai politik dengan tujuan untuk mendapat kuasa politik dan mengambil kedudukan politik. Dalam memperoleh kedudukan dan kekuasaan politik, harus tetap dilakukan dengan cara elegan demi mencapai tujuan dan substansi demokrasi. Partai politik tidak perlu mencapai tujuannya dengan mengorbankan substansi demokrasi dengan cara-cara pragmatis, khususnya di ajang kompetisi resmi untuk memperoleh kekuasaan secara konsitusional, yaitu Pemilu. Dikhawatirkan, sikap pragmatis partai politik tersebut, justru mencederai tujuan dan substansi demokrasi.

Kecenderungan pragmatis dalam memenangkan Pemilu mengancam demokrasi, terutama untuk mendapatkan calon pemimpin negara yang jujur, kredibel, dan kompeten. Masyarakat pemilih berhak mendapatkan manfaat dari sistem demokrasi ini. Kemampuan kalangan selebriti dalam dunia politik khususnya dalam mencalonkan diri menjadi kandidat tidak 
dipercaya rakyat sehingga menimbulkan dampak paling besar terhadap kehadiran selebritas dalam dunia politik.

Pada umumnya, keraguan akan kompetensi mereka kerap dijadikan masalah sebagai celebrity politician. Selebriti yang menjadi politisi memiliki berbagai masalah seperti yang dikatakan John Street (2012), pertama, dalam proses kebijakan terdapat masalah (potensi) peran mereka. Tiap wakil rakyat memberikan kemampuan sendiri terhadap pembuatan kebijakan. Kedua, terkait dengan pemberian informasi dalam alur media, seperti penyebaran asset simbolik kehadiran kalangan artis pada politik menjadi sebuah tendensi di era ini. Koneksi, fungsi negara yang menurun, meleburnya jati diri, dan dampak media berkaitan dengan pergeseran dari hierarkhi. Pemahaman selebriti tentang ideologi partai politik selain soal kompetensi secara umum, sama pentingnya untuk diperhatikan. Mark Wheeler (2013) mengamati jika selebriti memiliki pemahaman substansi ideologi, keterkaitan kalangan artis akan berperan penting bagi demokrasi.

Ketiga, meski mempunyai lebih kompeten, peluang kandidat selain selebriti memiliki peluang kecil yang tidak populer. Faktor "kenal" dengan calon legislatif juga dikedepankan oleh banyak masyarakat Indonesia. Keempat, strategi instan merekrut selebriti di dalam Pemilu makin banyak digunakan partai politik. Berkaca pada Pemilu-Pemilu legislatif sebelumnya, merekrut non-selebriti membutuhkan biaya yang lebih kecil dibandingkan hanya mengandalkan stratego pemilihan calon dari kalangan artis.

Ada beberapa alasan terhadap hal tersebut, meskipun pendapat ini tidaklah selalu benar. Pertama, tingkat elektabilitas pada Pemilu tidak tinggi, bahkan sangat kecil berdasarkan hasil keterpilihan selebritas Partai Nasdem pada Pemilu 2019. Kedua, pemilih cenderung tidak memilih selebriti (Darmawan, 2015). Berdasarkan penelitian Zwarun dan Torrey (2011) memaparkan bahwa pola piker selebriti yang hanya memiliki popularitas saja bagi para pemegang suara merupakan faktor ketidakterpilihan selebriti dalam sebuah Pemilu. Pemilih tidak memikirkaan kualifikasi ideal yang dibutuhkan seseorang ntuk menjadi kandidat calon legislatif.

Diluar popularitas, aspek umum yang menjadi factor pendorong keterpilihan seseorang dibagi menjadi enam dimensi, yaitu perlengkapan pribadi kandidat, pengalaman dunia politik, kredibilitas calon, metode dan sarana penyampaian pesan, strategi kampanye, dan pengaruh yang diberikan pada pemilik suara (Alsamydai \& Khasawneh, 2013). Sedangkan kompetensi, kepemimpinan, integritas, dan empati merupakan aspek lain sebagai spesifiksi seorang kandidat pada Pemilu. Intelligence dan pengetahuan calon dipacu pada aspek kompetensi. menginspirasi" dan "kepemimpinan kuat" terdapat pada kepemimpinan. "moral" dan "kejujuran" menjadi pengukur integritas. Kedudukan layaknya "compassionate" dan calon "acuh pada pemilik suara" berdasarkan empati.

Jika partai politik tidak menyajikan calon tersebut, maka diperlukan koreksi terhadap motivasi dan pragmatisme partai politik. Dengan kriteria tersebut, Partai Nasdem dalam kaitan pencalonan selebritas untuk memenangkan Pemilu, perlu menjawab melalui evaluasi dan perbaikan strategi dalam menghadapi Pemilu berikutnya. 


\section{Simpulan}

Sebagaimana yang dialami oleh berbagai partai politik di dunia, partai-partai politik di Indonesia, mengalami perubahan. Perubahan tersebut, sebagaimana Davis (2019) ungkapkan, adalah dari catch-all parties" menjadi "electoral-professional parties". Beberapa penyebab perubahan ini, selain dikendalikan pada pergeseran "sisi permintaan" atau "sisi penawaran", juga disebabkan oleh siaran media yang berdampak pada proses interaksi masyarakat. Partaipartai politik yang walnya bersifat tradisional dan berorientasi pada ideologi dan produk (product-oriented parties/POPs), tertransformasi menjadi partai berorientasi penjualan (salesoriented parties/SOPs) yang lebih canggih. Mereka masih mengambil posisi ideologis tetapi menggunakan pemasaran komersial modern dan praktik promosi untuk melakukannya. Partai semacam ini akhirnya bergerak kepada orientasi pasar (market-oriented parties/MOPs).

Meskipun berubah menjadi electoral-professional menjadikan partai-partai politik menjadi komunikator yang lebih baik, peka kepada publik, rasional dan profesional daripada sekedar ideologis, tetapi transisi ini membuat mereka terlalu berorientasi pada kepentingan elit dan asal menang Pemilu daripada sungguh-sungguh mewakili anggota dan publik yang lebih luas. Demikian pula, sales-oriented parties maupun market-oriented parties, sangat dipengaruhi oleh praktik dan personel promosi komersial, dan mengakibatkan penurunan peringkat kebijakan.

Gejala ini juga dialami partai politik di Indonesia. Puluhan partai bertahan dari ratusan yang lahir di era reformasi 1998, bertransformasi mengubah diri menjadi electoral-professional parties yang berorientasi panjualan maupun orientasi pasar. Demikian pula, partai-partai politik yang lahir beberapa tahun setelah reformasi 1998, langsung menyesuaikan diri dengan posisi dan orientasi tersebut, tak terkecuali Partai Nasdem yang lahir pada tahun 2011. Partai Nasdem dengan kekuatan korporasi Media Grup milik Surya Paloh di kepesertaan pertama pada Pemilu 2014 memperoleh 6,72\% suara nasional. Sebagai partai baru, perolehan suara ini dinilai karena kekuatan dana dan dukungan pemanfaatan media yang maksimal dari pemilik korporasi media tersebut. Dari sisi strategi, dukungan dana dan media ini merupakan modal strategi push dan pull political marketing yang sangat signifikan bagi Partai Nasdem. Oleh karena itu, pada kepesertaan kedua pada Pemilu 2019, Partai Nasdem tinggal memperkuat strategi pass political marketing yang sejak awal dianggap masih lemah karena sebagai partai baru, Nasdem belum memiliki banyak tokoh politik dan figur populer.

Pada Pemilu 2019, Partai Nasdem mencalonkan 38 selebritas dari 59 selebritas yang ada, jauh melebihi jumlah selebritas yang dicalonkan oleh partai-partai politik lainnya. Hal ini disamping untuk memperkuat strategi pass political marketing, dimungkinkan karena sistem proporsional terbuka memungkinkan siapapun tampil sebagai calon legislatif. Namun, strategi Partai Nasdem pencalonan selebritas dalam menghadapi Pemilu dengan sistem proporsional terbuka ini, dinilai bermotif pragmatis untuk sekedar untuk memenangkan Pemilu semata. Penilaian ini tidak keliru, karena hasil Pemilu menunjukkan bahwa dari 38 selebritas, hanya 1 orang selebritas yang terpilih menjadi anggota legislatif. Posisi calon legislatif selebritas yang hanya terkonsentrasi di empat provinsi menunjukkan persaingan calon legislatif dari Pertai Nasdem tidak sanggup memenuhi kriteria pilihan pemilih. Hasil ini memperkuat penilaian sikap pragmatisme Partai Nasdem dalam Pemilu 2019. 
Pragmatisme partai adalah akibat adanya keterlibatan logika untung-rugi, benefit-defisit, serta logika-logika matematis-ekonomis lainnya, dalam memutuskan strategi. Sikap pragmatis tersebut tidak terlepas dari motivasi akan pemenuhan kebutuhan kekuasaan (need for power). masyarakat selaku pemilih (electorate) pada akhirnya dipengaruhi oleh tindakan pragmatisme dalam Pemilu yang dikedepankan oleh parpol dan calon legislatif. Tingkat loyalitas rakyat pada parpol yang cukup minim dan kandidat juga terpengaruh oleh sikap pragmatisme partai politik layaknya efek domino.

Perubahan entuk vote getter mengenai celebrity endorser menjadi vote getter tentang celebrity politician mencakup hubungan selebriti dalam Pemilu di Indonesia. Paling tidak hal tersebut dikarenakan oleh pertama, peralihan proporsional terbuka suara terbanyak sedangkan sebelumnya dari proporsional tertutup. Kedua, pada walnya berdasarkan aliran (ideologi partai politik) kemudian cenderung berdasarkan pada tokoh tunggak pada pemilihan calon di Indonesia. Ketiga, banyak parpol di Indonesia semakin bersifat pragmatisnya. Alasan ini pula yang menjadi dasar Partai Nasdem dalam menghadapi Pemilu 2019.

Jika hal tersebut terus dilakukan oleh Partai Nasdem, dan partai-partai politik lain pada umumnya, substansi dan tujuan demokrasi yang berjalan di Indonesia, akan tercederai. Demokrasi akan tercederai jika sebagai calon penyelenggara negara, akan terbawa watak selebritasa, dan bukan berjiwa melayani dan mementingkan masyarakat. Demokrasi bertujuan mendapatkan wakil rakyat yang ideologis sekaligus profesional. Sehingga, strategi partai-partai politik, perlu dilakukan dengan pertimbangan idealisme dan profesionalitas. Pemilih berhak mendapatkan manfaat demokrasi. Diperlukan koreksi terhadap motivasi Partai Nasdem, maupun partai-partai politik di Indonesia secara umum, maupun sistem Pemilu proporsional terbuka, agar proses demokrasi dapat mencapai tujuan sebenarnya.

\section{Daftar Pustaka}

Alsamydai, M. J., \& Khasawneh, M. H. (2013). Basic Criteria for the Success of the Electoral Candidates and their Influence on Voters' Selection Decision. Advances in Management \& Applied Economics, 3, 105-127.

Belt, T. L. (2011). How Celebrities Become Political During Times of Threat. 9th Annual American Political Science Association, Pre-Conference on Political Communication.

Darmawan, I. (2015). Keterlibatan Selebriti Dalam Pemilu Indonesia Pasca Orde Baru. Sosiohumaniora, 18, 236242.

Davis, A. (2019). Political Communication: A New Introduction for Crisis Times. Polity Press.

Dugaswara, A. (2019, December 3). Sistem Pemilu Dan Pragmatisme Partai Politik. Https://KotaSukabumi.Kpu.Go.Id/Sistem-Pemilu-Dan-Pragmatisme-Partai-Politik/.

Emzir. (2010). Metodologi Penelitian Kualitatif Analisis Data. PT Rajagrafindo Persada.

Fadhli, M. R. (2016). Strategi Kemenangan artis dalam Pemilu Legislatif 2014. Prodi Ilmu Politik, FISIP UIN Syarif Hidayatullah.

Firmanzah. (2017). Mengelola Partai Politik: Komunikasi dan Positioning Ideologi Politik di Era Demokrasi. Yayasan Obor Indonesia.

Garnesia, I. (2019, July 17). "Benarkah Caleg Selebritas Bantu Nasdem Dongkrak Suara Pileg?" Https://Tirto.Id/Benarkah-Caleg-Selebritas-Bantu-Nasdem-Dongkrak-Suara-Pileg-Eegb.

Imawan, R. (2004). Pidato Pengukuhan Jabatan Guru Besar dalam Ilmu Politik pada Fakultas IImu Sosial dan IImu Politik Universitas Gadjah Mada. Partai Politik Di Indonesia: Pergulatan Setengah Hati Mencari Jati Diri.

Jati, W. R. (2014). Politik Selebritas Elaborasi Teoritik Terhadap Model Kampanye Baru. Jurnal Kawistara, 4, 183. 
Kenawas, Y. C., \& Fitriani. (2013, May 31). Indonesia's next parliament: celebrities, incumbents and dynastic members? Https://Www.Eastasiaforum.Org/2013/05/31/Indonesias-next-Parliament-CelebritiesIncumbents-and-Dynastic-Members/.

Magleby, D. (2011). Financing the 2008 Election. The Brookins Institute.

Menocal, A. R. (n.d.). Why electoral systems matter: an analysis of their incentives and effects on key areas of governance.

Muhtadi, B. (2013). Perang Bintang 2014: Konstelasi dan Prediksi Pemilu dan Pilpres. Mizan.

Nazir, M. (2013). Metode Penelitian. Penerbit Ghalia Indonesia.

Perdana, I. H. (2012). "Political Marketing Partai Politik baru menuju Pemilu 2014. Studi kasus; Strategi Pemenangan Partai NasDem.

Rahayu, U. (2019, April 29). Nasdem Meraupu Berkah dari Para Artis. Https://Kumparan.Com/@kumparannews/Nasdem-Meraup-Berkah-Para-Artis-1qyzGmIYfwF.

Ramdani, M. D., \& Arisandi, F. (2014). Pengaruh Penggunaan Sistem Pemilihan Umum Dewan Perwakilan Rakyat Proporsional Daftar Terbuka. Jurnal RechtsVinding, 3.

Romli, L. (2011). Reformasi Partai Politik dan Sistem Kepartaian di Indonesia. Jurnal Politica, 2.

Street, J. (2012). Do Celebrity Politics and Celebrity Politicians Matter? British Journal of Politic, 14, 346-356.

Swanson, D., \& Mancini, P. (1996). Politics, Media and Modern, Democracy: An International Study of Innovation in Electoral Campaigning and Their Consequences. Praeger Press.

Wicaksono, M. A., \& Aziz, Muh. S. (2020). Selebritas dalam Pemilu 2019. Journal of Southeast Asian Communication, 1(1).

Yudistira. (2015). Pelembagaan Partai Nasdem. Jurnal Mahasiswa Ilmu Pemerintahan Universitas Brawijaya, 1. 